\title{
A regional head election's political corruption and new styles of clientelism
}

\section{Korupsi politik pemilihan kepala daerah dan klientelisme gaya baru}

\author{
Muhammad Habibi \\ Badan Pengawas Pemilihan Umum Republik Indonesia \\ Address: Jalan M.H. Thamrin No.14, RT.8/RW.4, Gondangdia, Menteng District, \\ Central Jakarta, Jakarta Capital Special Region, Indonesia 10350 \\ E-mail: habibi.id@gmail.com
}

Article History: 18 April 2020; Received 18 October 2021; Published Online 29 November 2021

\begin{abstract}
Intense competition in the regional head election (Pilkada) has implications for the increasing costs that candidates have to prepare to win the competition. The high cost in the regional head election makes many regional heads, when elected, commit political corruption and practices that are more adapted to the situation, namely the new styles of clientelism. This study aims to determine the shift in the relationship between political corruption and clientelism and to see new forms of clientelism. The approach used in this research was a literature study. Documents were selected using an application from the Publish or Perish database. The results of this study indicate that first, the power of money in politics in Indonesia creates a significant dependence on economic power, which influences a high level of political corruption. Second, there are two new styles of clientelism, including buying and selling votes and patronage in the bureaucracy. This paper concludes that the various modes of political corruption and new styles of clientelism that occur underline political vulnerabilities at the local level due to the broad elaboration of regional authority discretion.
\end{abstract}

Keywords: crisis of democracy; new style of clientelism; political corruption

\begin{abstract}
Abstrak
Persaingan yang ketat dalam Pilkada berimplikasi pada besarnya biaya yang harus disiapkan calon untuk menang kompetisi. Besarnya biaya dalam pemilihan kepala daerah membuat banyak kepala daerah ketika terpilih melakukan korupsi politik dan praktik yang lebih menyesuikan keadaan yaitu klientelisme gaya baru. Tujuan penelitian ini untuk mengetahui pergeseran hubungan antara korupsi politik dan klientelisme, serta melihat bentuk klientelisme gaya baru. Pendekatan yang digunakan dalam penelitian ini adalah studi literatur. Dokumen dipilih menggunakan aplikasi dari basis data Publish or Perish. Hasil penelitian ini menujukkan bahwa pertama, kekuatan uang dalam politik di Indonesia menciptakan ketergantungan yang besar terhadap kekuatan ekonomi sehingga mempengaruhi tingginya korupsi politik. Kedua, terdapat dua gaya baru klientelisme, yaitu jual beli suara dan patronase di birokrasi. Tulisan ini menyimpulkan bahwa berbagai modus korupsi politik dan klintelisme gaya baru yang terjadi mempertegas kerawanan politik di tingkat lokal sebagai akibat dari penjabaran luas diskresi kewenangan daerah.
\end{abstract}

Kata kunci: krisis demokrasi; klientelisme gaya baru; korupsi politik

\section{Introduction}

It is a general agreement that corruption is a practice that is extremely damaging to the foundations of national life. Corruption is believed to cause a decline in government legitimacy, damage to public services, and humanity's declining quality of life (Nye 1967, Mietzner 2015, Fisman \& Golden 2017, Gong \& Scott 2017). It turns out that corruption is still widespread and even permissively responded to with various excuses. A corruption perception index survey conducted by Transparency International Indonesia (TII) in 2017 found that the most significant inhibiting factor in eradicating corruption is the perception that corruption is not considered an important issue (score 61.5 out of 100) can be seen in Figure 1. 
Disclosure of corruption cases is considered an effort to divert public attention from other political issues. The handling of corruption cases is also often interpreted as a form of a power struggle to "get rid" of political opponents from the competition arena (Rose-Ackerman 1999). On the other hand, not a few corruptors who fought in the era of Pilkada still received the support of votes. This phenomenon shows the complexity of the current corruption problem, especially when corruption practices intersect with the dynamics of political struggle in the holding of various electoral events, both at national and local levels (Heywood 1997, Kawata 2006, Habibi 2020). Data released by the Corruption Eradication Commission (KPK) in 2021 shows that from 2004-2020 there were 150 regional heads, consisting of 21 governors and 129 mayors/regents, who were involved in corruption cases.

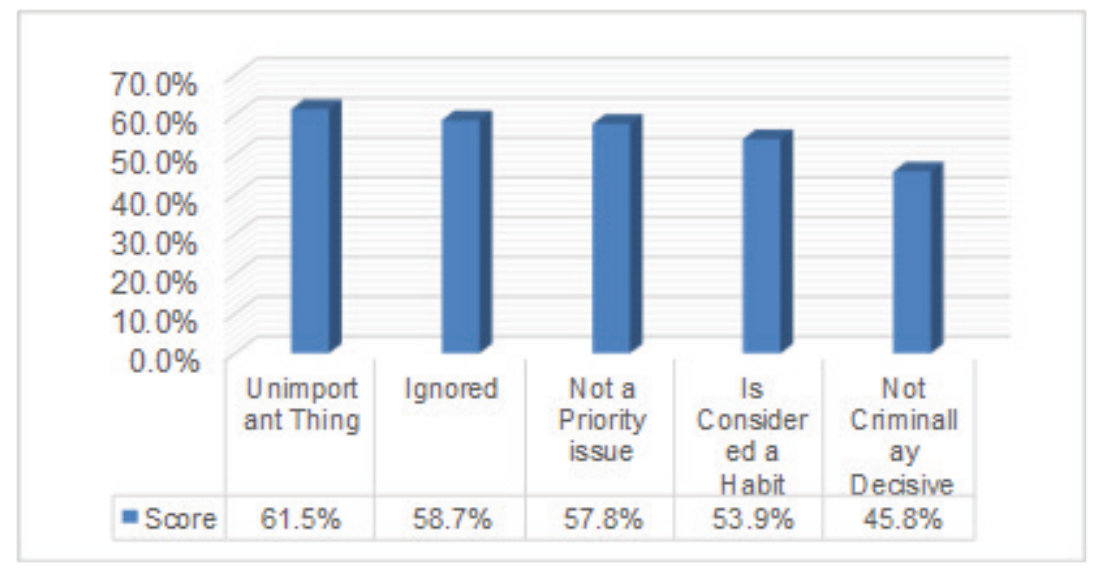

Figure 1.

Factors inhibiting corruption eradication

Source: TII (2017)

The research conducted by TII (2017) found five factors that entrepreneurs consider to hinder the eradication of corruption. As a result of this existence, corruption continues to occur and repeats itself. The five factors are that corruption is not considered an important phenomenon (61.5\%), corruption is allowed (58.7\%), corruption is considered a policy priority (57.8\%), and corruption is considered a habit $(53.9 \%)$. Moreover, lastly, the perpetrators of corruption are not strictly punished (45.8\%).

The development of the corruption rate of regional heads, coupled with five factors that hinder the eradication of corruption, is quite worrying for the journey of democracy in Indonesia, especially in the context of electoral democracy. Since the regional head election was held directly, the number of regional heads caught in corruption has increased (Dalilah et al. 2019). Pusat Penelitian dan Pengembangan Pengawasan BPKP (2018) found a tendency for increasing cases of corruption by regional heads due to power monopolies, policy discretion, weak accountability of lack of competence in public financial management, and the high cost of the regional head election.

Similarly, research conducted by Mietzner (2015) \& ICW (2018) found the that root cause of the rampant corrupt practices carried out by regional heads was the tight competition. It has implications for the costs that candidates had to prepare to win electoral competitions. These costs are allocated during the campaign period and in the previous period when candidates begin to socialize themselves to the final stage of the election, which is to oversee the vote-counting results until the election results are determined. At that stage, the costs that need to be prepared are for witnesses at the polling station (TPS). In addition to these stages, if the candidate pair disputes the vote count results, the candidate must also be ready in funding, both for filing, lawyers, and accommodation. The Ministry of Home Affairs estimates the political costs required to become a regent/mayor of IDR 20-30 billion, while to become a governor requires IDR 20-100 billion to win regional elections (ICW 2018). 
On the other hand, political parties that play a strategic role in the nomination do not have adequate funding sources to meet funding needs in all stages of the election. Law No. 2 of 2011 concerning the Second Amendment to Law Number 2 of 2008 concerning Political Parties, article 34 states that political parties have 3 (three) financial sources, including membership fees, legal contributions, and financial assistance from the State Revenue and Expenditure Budget / Regional Revenue and Expenditure Budget. Nevertheless, the practice that often occurs precisely shows the tendency of parties to provide support from external parties to candidates to meet the party's need for operational funds and enormous political costs (Mietzner 2015, Irham 2016). The cause of widespread political corruption is transactional practices.

The various corruption cases revealed in Indonesia show that eradicating corruption cannot rely solely on formal democratic institutional mechanisms because those elected through this mechanism are also trapped as perpetrators of corruption. This mode indicates the link between the abuse of authority and the election of regional heads, which makes this type of corruption included in the category of political corruption (Kawata 2006, Heidenheimer \& Johnston 2007, Heywood 2015, Gong \& Scott 2017). In contrast to the research conducted by Kawata (2006), Heidenheimer \& Johnston (2007), Heywood (2015), and Gong \& Scott (2017), which only focuses on discussing political corruption, this article seeks to discuss the shifting relationship between corruption and clientelism, as well as see a new form of clientelism, which makes clientelistic relations are transforming into the more competitive practices of electoral democracy.

\section{Research Method}

The approach used in this research was the study of literature used primarily to explain the links between political corruption and the formation of new styles of clientelism. Documents were selected using an application from the Publish or Perish database. This study collected data from journals, books, reports, and news regarding clientelism, political corruption, and election fraud. All documents collected were filtered by reading and identifying the data that could support the research and collecting documents containing various countries' political corruption, clientelism, and electoral fraud. The data were compared by forming comparative data based on the reality in the Indonesian elections obtained from journals, books, reports, and news sources.

The data were then analyzed using data reduction, display, and conclusion drawing/verification (Miles et al. 2014). The researcher began by mapping the current understanding of political corruption and clientelism, especially in electoral democracy with an open competition system. The following section discusses the various modes of political corruption that indicate the transformation of clientelism and its implications for the distributive politics of resources. The concluding section concludes the distributive politics relevant to fighting clientelism that leads to political corruption.

\section{Results and Discussion}

\section{Regional head election}

In principle, the regional head election is regulated in Article 18 paragraph (4) of the 1945 Constitution of the Republic of Indonesia. Although the term regional head in Article 18 paragraph (4) of the 1945 Constitution is known as the head of regional government, it can be understood as chief of the executive (Hoesein 2010). As stated in Article 18 paragraph (4) of the 1945 Constitution in principle, the election of regional heads lies in the fragment of the sentence "elected democratically". This fragment of the phrase "elected democratically" means that Pilkada can be conducted directly or indirectly. The direct election of regional heads means that citizens elect the governor and his/her deputy, the regent/mayor, and his/her deputy directly. Meanwhile, the election of regional heads carried out indirectly means that the election of the governor and his/her deputy, regent/mayor, and his/her deputy is determined through the Regional People's Representative Council (DPRD). 
The regulation states that the regional heads are democratically elected. In addition, Law No. 1/2015, article 2, Law No. 1 of 2015 states that governors/deputy governors, regents/deputy regents, or mayors/ deputy mayors are elected in pairs through democratic elections based on the principles of direct, general, free, confidential, honest, and fair (principles of overflow) or called "luber jurdil".

The elaboration of the principle of "luber jurdil" is as follows: the principle of direct means that the people as voters have the right to cast their votes directly following the will of their conscience without intermediaries (Akbar et al. 2021). However, in the case of Pilkada, the direct principle is not entirely applicable in several unique regions, such as the Special Region of Yogyakarta, Papua Province, and DKI Jakarta. In Yogyakarta, the governor is not directly elected but is passed down from generation to generation. In Papua Province, several districts use the 'noken' system. It is an electoral system in which voters cannot directly vote according to their will but are represented by customary leaders in their territory and only carried out in certain areas in the Province of Papua. It also applies to the Special Capital Region of Jakarta, where the mayor and regent are not directly elected by residents of DKI Jakarta. The categorization of "special" is normatively explicitly regulated in Article 18B paragraph (1) of the 1945 Constitution of the Republic of Indonesia.

Furthermore, the understanding of the general principle is the existence of opportunities that apply thoroughly to all citizens without discrimination. Then the principle of freedom in elections is defined as every citizen with the right to vote is free to make his/her choice without pressure and coercion from anyone. The principle of honesty is that election organizers, government officials, election participants, election supervisors, election observers, voters, and all related parties must behave and act honestly following the laws and regulations. At the same time, the principle of fairness is that every voter and election participant gets the same treatment and is free from fraud by any party (Akbar et al. 2021).

\section{Clientelism and political corruption in electoral democracy}

Rose-Ackerman (1999) distinguishes two patterns of relations between the political system and the tendency for corruption. In the first pattern, the political system produces policies with clearly targeted targets of beneficiaries so that it does not trigger corrupt practices to compete for influence over the policies. With that limitation, the political system has shown partiality in specific target groups. However, groups that do not directly benefit from the policy can also seek to gain access to the policy process through legally donating campaign funds and bribery or illegal campaign funding. In that context, political corruption practices continue to occur but are responded with more tolerance because the public has known and placed the political system as an institution in favor of certain groups. The implication is that clientelistic relationships are formed between two clients, including those who directly benefit from the power and those who seek to "buy" influence by bribing policymakers. In this pattern, clientelistic relations and corrupt practices can occur simultaneously even though they involve parties. For example, in making policies or programs, politicians can give the program to those who provide gratuities or bribes while still providing benefits to clients in the form of a pork-barrel program (expenditure that a politician or member of parliament makes for his/her constituents in exchange for political support, whether in the form of campaigning or voting in elections) (Habibi \& Suswanta 2019).

In the second pattern, the public will respond more decisively to corrupt practices in a more competitive political context even though they continue to benefit from policies or programs resulting from clientelistic practices (Rose-Ackerman 1999). Competition between political actors also impacts the high offer from parties who strive for their respective interests. The competition takes place in the political arena to obtain leadership positions and offers made to politicians to make policies according to the interests of certain groups. Deviations that lead to corrupt practices take place through political processes outside the formal mechanism. The prominent mode carried out is through the bribery of politicians. The second pattern shows that corruption is still likely to emerge in a competitive political system. Political negotiations that take place informally and are not monitored by the public are prone to corruption, both in the form of pork barrels and programmatic politics on a broader scale. 
On a different side, Daniel Corstange analyzes the clientelistic relationship pattern between political parties and voters (Corstange 2018). Political parties use clientelism to determine whom voters need to be given money in return for votes cast (Gans-Morse et al. 2014). The higher the level of contesting votes, the greater the incentives that must be prepared by political parties to obtain votes from voters. Priority is generally directed at voters who are not easily swayed as targets to obtain incentives from political parties. The most common model in the clientelistic pattern between parties and voters is votebuying. Although it is a form of violation in elections, this practice is different from political corruption because it does not involve abuse of authority about public resources. However, political corruption can be a way for parties to meet the funding needs to buy votes. With the limited sources of campaign finance that can be obtained, corruption is a pragmatic solution for political parties that use a clientelistic approach to continue to gain votes in the era of electoral competition.

The practice of clientelism that takes place in an electoral context illustrates how distributive politics prevails. Distributive politics determines to whom the party will provide incentives, where the sources of incentives are, and what methods are used to distribute the incentives (Cox 2010). For new democracies, studies conducted by Jong-sung You in Korea, Taiwan, and the Philippines found that economic inequality in the form of land tenure structures has encouraged the practice of clientelism and the raise of elites who control power (capture) and increase corrupt political practices (You 2014). Economic inequality is causing an increase in the "number" of clients on one side. On the other hand, economic inequality encourages wealthy politicians to strengthen clientelism relations by no longer using programmatic political strategies. It also increases the possibility of power control for personal or group interests. In other words, high economic inequality will increase the pressure of redistribution from the community so that the rich have more incentives and the ability to corrupt and control the government to respond to the pressure of redistribution.

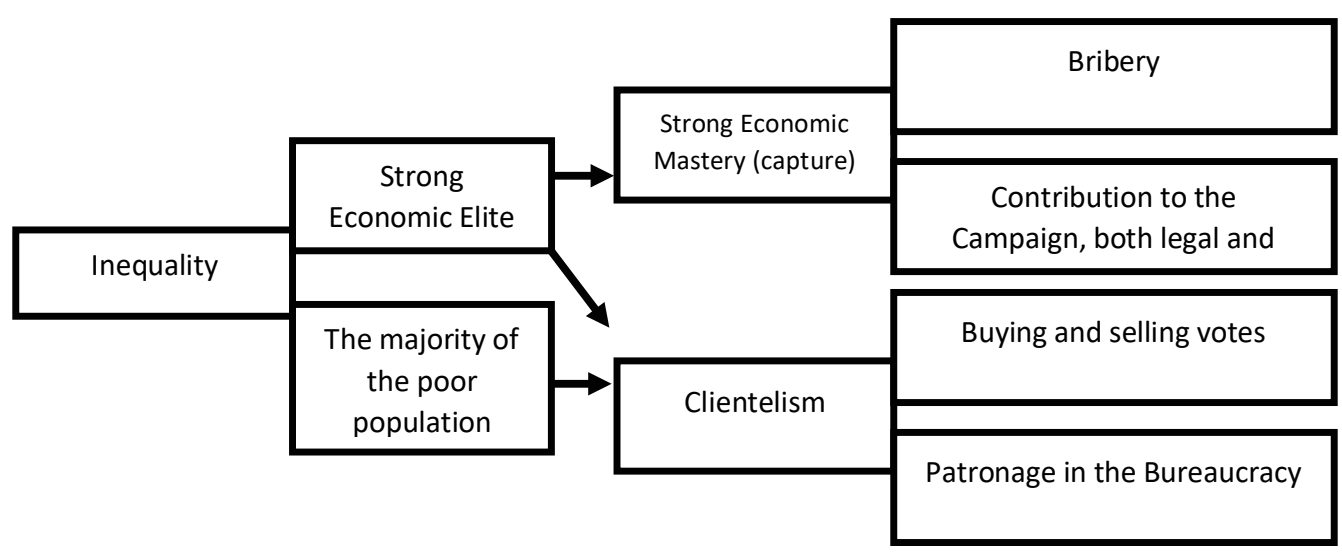

Figure 2.

Realization between economic inequality and political corruption Source: You (2014)

Figure 2 shows the new styles of clientelism adopted from Jong-sung You's findings, showing two forms of clientelism. They are buying and selling votes, which is a form of clientelism that occurred during the regional head election. A survey conducted by Lembaga Survei Indonesia (LSI) conducted on 11-14 December 2020 shows that $63,1 \%$ of voters are involved in this illegal practice (LSI 2021). Furthermore, a survey released by Muhtadi in 2014 shows that there were $33 \%$ of people claimed to receive money to vote (Muhtadi 2018). Remember that in the 2020 Pilkada, 100,3 million were registered on the Permanent Voters List (DPT). Therefore, 63,1\% suggests that 63,3 million people have been offered money politics. The practice of buying and selling votes puts Indonesia in third place in the world as a country that has the most money politics. Indonesia is only less competitive than Uganda (41\%) and Benin (37\%). This data is based on data on money politics (vote buying) from various countries in Asia, Africa, and America obtained from trusted surveyor associations such as The Latin American 
Public Opinion Project (LAPOP), Americas Barometer, Afrobarometer, and Money Politics Project in Southeast Asia (Muhtadi 2018).

Patronage in the bureaucracy, several candidates for regional heads claimed to have sponsors to fund the Pilkada from the State Civil Apparatus (ASN). This is similar to the survey results of the Corruption Eradication Commission (Indonesian: Komisi Pemberantasan Korupsi, abbreviated as KPK) of several regional head candidates who competed in 2015, 2017, and 2018 Pilkada (Saubani 2020). It is suspected that there was an attempt to repay the service from the regional head to ASN who mobilized funds during the Pilkada, especially ASN who occupy the position of head of a service or head of the agency. Incidentally, it is controlled by the ASN, not the official success team. However, they are making efforts so that the regional head candidate they support wins the regional head election.

In an increasingly competitive arena of electoral democracy, clientelistic relations can occur between political parties and voters and between elite policymakers and various interest groups. Corruption and clientelism are often linked because they both lead to political actors who abuse public resources for personal gain, both financially and politically. Corrupt practices such as bribery or gratification do not have to take place in clientelistic relationships. Clientelism will lead to political corruption in the abuse of authority in allocating and distributing public resources (Habibi 2020). To maintain the legitimacy of power, incumbents also use distributive politics as an instrument to determine who will benefit from available resources. In that context, the authority to determine the distribution of vulnerable public resources leads to political corruption. The link between clientelism and political corruption began to shift. It is no longer about small-scale bribery practices but rather a more systematic and massive pattern related to accumulating funds to maintain power.

\section{Clientelism transformation}

In conditions where law enforcement is weak and bureaucracy is politicized, clientelistic relations are likely to lead to corruption. Clientelism and corruption co-exist and mobilize funds to obtain resources distributed by political machines, such as political parties, success teams, interest groups, and even voluntary organizations in current political practices. Clientelism is often associated with corruption because it can create a political structure for the growth of corruption. It requires politicians and bureaucrats to have discretionary authority in allocating resources and public programs, and the exchange between discretion of authority and public resources takes place without public scrutiny (Singer 2009, Stokes et al. 2012). It creates incentives for politicians to reject changes that will bring transparency and accountability or strengthen enforcement law; even politicians tend to weaken various regulatory boundaries in the political system, which will disrupt the sustainability of clientelism practices (Stokes et al. 2012).

Assessment of non-performance bureaucracy will also impact resource management efficiency, thus encouraging people to obtain services by giving bribes and kickbacks to facilitate business with bureaucracy. It can be seen in the phenomenon of Ijon Politics for mining business permits, where entrepreneurs make donations to campaigns for regional head candidates in the hope that if elected later, the mining business permit process will be obtained easily and their business is safe from interference (Habibi 2020, Katadata 2020).

In the end, clientelism will produce a government system with weak accountability, opaque decisionmaking, and a high level of authority discretion. The condition also becomes fertile ground for the practice of political corruption. In that condition, political actors have an excellent opportunity to seek rent because of the community's need to overcome the bureaucratization of the provision of public resources. Besides, weak law enforcement also seems to justify such deviant behaviors (Rose-Ackerman 1999). 
Other conditions that can change clientelistic relations to corruption stem from the need to finance the supply of public goods and services that will be exchanged. To provide for this need, politicians can use their authority to develop programs that directly benefit their supporters or change the budgeting scheme from government programs to the electoral treasury (Kitschelt \& Wilkinson 2009). In that context, corrupt clientelistic relations manipulate the distributive politics of the state to provide public resources for transactional political interests.

The pattern above shows that authority over public resources is used to accumulate the capital needed to meet political costs in elections. Clientelistic relations are no longer dyadic as in the concept of Scott (1972) but shift more pragmatically. Because it involves authority in the distribution of public resources, the practice of corruption that arises from pragmatic clientelistic relations is more extensive in scale, as indicated by the mode of corruption committed by regional heads who will re-nominate or nominate their relatives in the next election. Research by ICW found the post-election direct regional political corruption tends to be as shown in Table 1.

Table 1.

Corruption case with alleged election funding

\begin{tabular}{|c|c|c|c|}
\hline Case & Suspect & Position & Suspected \\
\hline Bribe import beef & $\begin{array}{l}\text { Luthfi Hasan } \\
\text { Ishaaq }\end{array}$ & $\begin{array}{l}\text { Member of the } \\
\text { Indonesian } \\
\text { Parliament/ } \\
\text { Chairman PKS }\end{array}$ & $\begin{array}{l}\text { Mentioned in the Supreme } \\
\text { Court Decision for Lutfi Hasan } \\
\text { Ishaaq that the suspects } \\
\text { Fathanah and Yudi Setiawan } \\
\text { met to discuss the plan to } \\
\text { consolidate the acquisition } \\
\text { of funds of Rp } 2 \text { trillion as a } \\
\text { fulfillment of the PKS target in } \\
\text { the } 2014 \text { election }\end{array}$ \\
\hline $\begin{array}{l}\text { Bribery project of } \\
\text { the Ministry of Public } \\
\text { Works and Public } \\
\text { Housing }\end{array}$ & $\begin{array}{l}\text { Damayanti Wisnu } \\
\text { Putranti }\end{array}$ & $\begin{array}{l}\text { Member of the } \\
\text { Indonesian } \\
\text { Parliament }\end{array}$ & $\begin{array}{l}\text { The witness said to fund the } \\
\text { regional elections in Central } \\
\text { Java in } 2015\end{array}$ \\
\hline $\begin{array}{l}\text { Management of funds } \\
\text { for health services in } \\
\text { Tegal City Hospital, and } \\
\text { other projects within } \\
\text { the City Government }\end{array}$ & $\begin{array}{l}\text { Siti Masitha } \\
\text { Soeparno and } \\
\text { Amir Mirza } \\
\text { Hutagalung }\end{array}$ & Mayor of Tegal & $\begin{array}{l}\text { It is suspected to fund the } \\
\text { suspect's progress in the } 2018 \\
\text { Tegal election }\end{array}$ \\
\hline $\begin{array}{l}\text { Bribery for the sake } \\
\text { of mining business } \\
\text { licenses in Tanah Laut }\end{array}$ & Adriansyah & $\begin{array}{l}\text { Member of the } \\
\text { Indonesian } \\
\text { Parliament }\end{array}$ & $\begin{array}{l}\text { Allegedly to fund the advance } \\
\text { of Adriansyah in the South } \\
\text { Kalimantan Election }\end{array}$ \\
\hline $\begin{array}{l}\text { Bribes for managing } \\
\text { oil palm plantation } \\
\text { concessions }\end{array}$ & Amran Batalipu & Regent of Buol & $\begin{array}{l}\text { Allegedly to fund the } \\
\text { advancement of Amran Batalipu } \\
\text { in the Buol election }\end{array}$ \\
\hline $\begin{array}{l}\text { Buying and selling } \\
\text { positions in the Klaten } \\
\text { District Government }\end{array}$ & Sri Hartini & Regent of Klaten & $\begin{array}{l}\text { Allegedly to fund the progress } \\
\text { of Sri Hartini in the Klaten } \\
\text { Regional Election }\end{array}$ \\
\hline $\begin{array}{l}\text { Buying and selling } \\
\text { positions in the } \\
\text { Nganjuk District } \\
\text { Government }\end{array}$ & Taufiqurrahman & Regent of Nganjuk & $\begin{array}{l}\text { Allegedly to fund his wife going } \\
\text { forward in the Nganjuk Regional } \\
\text { Election }\end{array}$ \\
\hline $\begin{array}{l}\text { Corruption of the } \\
\text { coastal abrasion dike } \\
\text { reconstruction project } \\
\text { in Biak Numfor District }\end{array}$ & Yesaya Sombuk & $\begin{array}{l}\text { Regent of Biak } \\
\text { Numfor }\end{array}$ & $\begin{array}{l}\text { The witness called the } \\
\text { perpetrator of the corruption to } \\
\text { repay the Pilkada's debt }\end{array}$ \\
\hline $\begin{array}{l}\text { Bribery of Market } \\
\text { development }\end{array}$ & Atty Suharti & Mayor of Cimahi & $\begin{array}{l}\text { Allegedly to advance in the } \\
\text { Cimahi regional election }\end{array}$ \\
\hline
\end{tabular}


The nine cases in Table 1 show the potential for collecting and returning election capital from corruption. Permit trading, bribery of policies, to the sale and purchase of positions were committed by regional heads to collect and return the election capital. The capital is needed to finance the five processes generally passed by candidates in elections and issue significant capital, both legal and illegal, including the process of nominating candidates, internal selection in political parties, campaigns, vote counting, and the process of resolving disputes. The first process is pre-oxidation; candidates promote themselves to the public and political parties to be nominated for a regional head. In the process, prospective candidates generally require funds to make and install props to socialize themselves, for example, in the form of billboards, holding populist events and conducting surveys.

Funding is also needed when candidates seek support from political parties in the nomination or selection phase in internal political parties. Political parties have never recognized the costs of internal nominations, but political dowry has circulated widely in society. Some cases that surfaced include La Nyalla Mataliti's statement claiming to be asked for IDR170 billion to obtain support from political parties in the election of East Java Governor 2018 (Defianti 2018) and Siswandi, a prospective candidate for Mayor of Cirebon, who claimed to be asked for dowry by one of the parties as a requirement to obtain nomination recommendations from the party (Nursanti 2018). Based on both statements, political dowry is needed for witness costs in counting votes, so the amount varies depending on the number of voters in the region. In addition to the two cases, it seems that the tendency of candidates to claim to be asked for political dowry by the party is starting to increase. Therefore, the issue of political dowry needs to be a concern in handling political corruption cases.

The next phase prone to corruption is the campaign period; candidates need to prepare many resources to make self-promotion and the program successful. Cases of vote-buying were rife at that stage and on polling day. In the voting phase, the need for costs that the party or candidate needs to prepare is the funds for witnesses' voting, counting, and escorting costs. The presence of witnesses in each polling station charged to political parties is a reason for the parties concerned to ask candidates to help provide funds for witnesses because the party does not have adequate sources of funds. The need for funds will increase if the outcome of the determination leads to a dispute. Candidates and parties need to prepare resources to oversee the dispute resolution process.

To meet the needs of these funds, Law Number 10 of 2016 concerning the Second Amendment to Law Number 1 of 2015 concerning the stipulation of Government regulations instead of Law Number 1 of 2014, concerning Election of Governors, Regents, and Mayors into Laws, Article 74 Paragraph (1) states that campaign funds for candidate pairs proposed by political parties or a combination of political parties can be obtained from contributions of political parties and/or joint political parties that propose candidate pairs, contributions of candidate pairs, and/or other non-binding contributions of other parties which includes contributions from individuals and/or private legal entities. Meanwhile, paragraph (2) regulates the provisions regarding campaign funding sources for individual pairs of candidates, which can be obtained from donations of candidate pairs, other non-binding contributions of parties, including individual contributions and/or private legal entities. The maximum amount of campaign fund contributions from other parties is IDR 75 million from individuals and a maximum of IDR 750 million from private legal entities. It excludes donations for candidate pairs, political parties, and/or a combination of political parties that propose candidate pairs. Individual candidate pairs may receive and/or approve donations that are not directly in the form of money for campaign activities which if converted based on market prices do not exceed donations of campaign funds from other parties.

The maximum limit for campaign fund contributions in this provision has been raised from the previous maximum limit. The maximum limit from individuals is IDR 50 million while that of private legal entities is IDR 350 million. The increase in the maximum limit for campaign funding contributions confirms the high costs of competing in electoral democracy today. However, on the other hand, the provision also provides a loophole for candidates or political parties to utilize clientelistic relations in 
optimizing their campaign funding sources. From the mode of political corruption found by various researches, funding needs stem from more public budgets or politicized development programs to gain support from voters (Pusat Penelitian dan Pengembangan Pengawasan BPKP 2018, ICW 2018).

Public budgets that are prone to corruption include licensing, social assistance and grants, village fund allocation programs, buying and selling official positions, and bribes to procure goods and services. The various modes indicate abuse of the authority of regional heads in many domains in the management of public affairs, such as budgeting, recruitment of regional officials, granting natural resource licenses, procurement of goods and services as well as making regional head regulations, and the existence of a dynasty of power. It causes the chief regions to commit corruption through bribery and gratification. Besides, the mode of political corruption also emphasizes the vulnerability of distributive politics at the local level due to the widespread translation of the discretion of regional heads so that management of public resources remains under the dominance of regional heads.

The phenomenon of state capture in distributive politics proves that competitive electoral democracy has not yet produced significant changes in governance for the public's welfare. In the context of pragmatic distributive politics, the head of the region uses his/her authority to establish transactional relations with the owners of capital, as illustrated by the mode of granting permits for resource management or procurement of goods and services to meet political funding needs. However, political corruption in electoral competition is unique because, through this mode, public resources are channeled to target groups. Although the motive is to optimize votes and political support, such populist distribution practices also contribute to the survival of political corruption. Therefore, it is not surprising that candidates suspected of being corrupt still obtain votes in elections (Kurer 2001). Therefore, efforts to eradicate political corruption must be balanced with radical changes in distributive politics so that access to public goods and services can be spread evenly across all strata of society.

\section{Freeing distributive politics from corruption trap}

Clientelistic relations are characterized by a combination of specifically determined goals and ongoing exchanges (Hicken 2011). In competitive electoral democracy, the person who becomes the target is determined by his/her capacity in providing support, not only in the form of votes but also in support of election funds. Cases of political corruption revealed in Indonesia after the direct election show that the forms of irregularities that occur are corruption on a massive scale; politicians give concessions, policies, or contracts for the procurement of goods and services to the owners of capital that are intended to explore the potential available funds as much as possible. A minor form of corruption cannot provide this because the funds generated are inadequate to finance the operation of the electoral political machinery and, consequently, cannot be channeled to elect clientelistic networks.

The writings of Budi et al. (2018) discuss the financing of the regional elections from the side of individual candidates in the 2018 Madiun City Election. First, the pattern of vote-buying in the nomination process of an individual candidate. Only with cooking oil for IDR 7,500, an individual candidate has managed to obtain one Identity Card (KTP) as a requirement for candidacy. This is added to the cost of introducing themselves, considering that the candidate is not domiciled in the local area, making him less popular among voters. Another finding is the capital-intensive campaign model of an individual candidate (Budi et al. 2018).

The phenomenon of botoh (financiers as well as political consultants for regional head candidates, also play a role in the support mobilization process, especially in vote-buying strategies) which is extremely popular in Central Java. Fitriyah \& Alfirdaus (2018) explain in detail the role of botoh in financing the election campaign. Botoh originally referred to gamblers who placed bets in the context of the village head election (Pilkades) without any intervention in the support mobilization process. However, as explained in this chapter, botoh later transformed into financiers and political consultants for candidates for regional heads so that they also played a role in the support mobilization process, especially in 
vote-buying strategies. As an investor, botoh contributes to financing money politics for regional head candidates with an agreement. The agreement is that if a candidate assisted by botoh can win the election, then the candidate will give twice the contribution of funds that have been issued by the botoh. However, if the candidate loses, the botoh will bear the loss from the existing fund contribution. Botoh then becomes part of mobilizing support for the candidate to ensure the candidate's victory through various essential activities such as winning electoral surveys or assisting the victorious team in voter mobilization (Fitriyah \& Alfirdaus 2018).

On the other hand, corrupt clientelistic practices are also compensated through populist development programs, which are expected to increase voice support and legitimacy for politicians (Kitschelt 2000). The presence of populist programs in the short term can meet the public's need for services, but these programs do not design for the long term so that its sustainability is highly dependent on the authority figure. Electoral democracy, which is increasingly competitive today, has changed the clientelism relation to a more pragmatic direction, where political corruption has become an instrument to distribute resources to the public. This shift raises a different face of political corruption, which no longer focuses on extortion practices but rather transactional practices of mutually beneficial parties. Even the parties involved can choose to participate or not based on the consideration of the benefits (Popa 2014). Clientelism in a democratic regime is used to strengthen the state capture of the ruling elite by distributing public resources through populist programs to gain public recognition. However, this choice has reduced the benefits of political elites from resource extraction and thus raises higher political costs to compensate for these shortcomings.

The practice of political corruption that is "disguised" in clientelistic relations and populist programs adds to the complexity of eradicating corruption due to the increasingly vague boundaries between lawlessness and the discretion of authority for the public interest. Therefore, the impact of the rise in political corruption is not only shown by the number of state losses but also inefficiencies in the management of public resources, which impact the slow distribution of goods and services. Distributive politics that are managed in a corrupt manner will only benefit individuals who can "pay" the government to obtain the public goods and services they need so that the allocation and distribution of public resources are not determined by their social benefits (Shleifer \& Vishny 1993, Olken \& Barron 2007). Socio-economic rights are the most frequently violated so that people with low economic levels become victims in the interests of the more significant, which are the conglomerate and the state (Dasahasta et al. 2013). People with lower economic classes are systematically and structurally violated their rights and impoverished by a corrupt system. They find it challenging to meet the necessities of life, such as the right to health, education, a place to live, work, and other rights because the system does not favor the people and is worsened by the proliferation of corrupt practices. The basic necessity to live appropriately is essentially a right that must be claimed by citizens and fulfilled by the country not only through shortterm populist programs.

Only certain people can access public resources. Even if other parties have access to these resources, they are usually those who can maintain the externalities of these resources so that not all people can obtain them. Therefore, the effects of corruption will damage public opportunities to obtain resources more efficiently. Even though some populist programs can reach more targets, when the programs are managed in a corrupt system, it does not solve the root problems of the welfare distribution system, which is the problem of limiting public access to resource management. Conversely, a corrupt system will always maintain access restrictions so that those who benefit from the system can determine who is entitled and not entitled to receive public resource benefits. Corrupt distributive politics limits not only public access to resources but also maintains manipulative power relations. Those who benefit from a corrupt system will tend to vote for candidates who can guarantee the system's sustainability so that even though elections are competitive, they will not be able to eliminate corrupt practices.

Today, political corruption in electoral democracy arises because high-cost political practices meet various needs during the electoral process, while adequate funding sources do not support political parties 
to the main instruments in elections. Election regulations also provide a great opportunity for individuals or private legal entities to contribute funds to candidates or political parties that compete in elections. This condition becomes a gap for the clientelism-corruption-clientelism cycle which shows state capture in the distributive politics of public resources. The state cannot occur when various political, economic, or social groups conspire to gain access to the distributive and regulatory authority of the state with the aim of personal gain (Trantidis \& Tsagkroni 2017). The dominance of the power of capital in funding political elections can cause political parties and candidates to be co-opted, and voter control of political parties and candidates is not possible, especially on issues that conflict with the interests of investors.

Determination of the power of money in politics in Indonesia as a country undergoing a political transition with a reasonably high fragmentation creates a significant dependence on economic power. It can lead to direct or indirect co-optation of political power. The phenomenon of an-sich capitalists becoming capitalist politicians and bureaucrat capitalists will be increasingly widespread. This phenomenon will be colored by the mastery of specific structures or budget posts in government for the position of businesspeople who indirectly also give political power to accumulate it. The composition of funding, dominantly controlled by the political elite and business groups, will create an oligarchic policy structure. As the leading public policy actors, oligarchic power will control political parties and candidates more efficiently.

The government must immediately make efforts to eradicate political corruption a priority, not reproduce oligarchic distributive politics. Fundamental changes must be made in the party system because political parties are a recruitment source for policymakers. All regulations produced in governance are made by actors whom political parties promote as regional head candidates and legislative members. Even though the electoral system is constantly being improved, it will still be counterproductive if the reforms are not balanced with improvements in the internal management of political parties, especially regarding party finances and authority in determining candidates.

Corruption mainly occurs because the enormous discretion of authority is not matched by accountability. Therefore, a fundamental change that must be immediately made in fixing the distributive politics of resources so as not to be co-opted by the elite is to increase accountability in the management of public resources. Accountability must also be upheld within the body of political parties as the main instrument in electoral democracy, especially in the electoral process prone to corrupt practices, such as pre-candidacy, candidacy, campaigning, and vote counting. Political parties need to develop an open and decentralized selection and candidacy process to demonstrate their commitment to eradicating political corruption. Finally, accountability must also be the principle that underlies the political funding system, determining funding sources for political party activities outside the election period and funding during the election.

\section{Conclusion}

The dominance of the power of capital in political election funding can cause political parties and candidates to be co-opted, and voter control of political parties and candidates is not possible, especially on issues contrary to investors' interests. Determination of the power of money in politics in Indonesia as a country undergoing a political transition with a reasonably high fragmentation creates a significant dependence on economic power. There are two new styles of clientelism, including vote-buying, which is a form of clientelism that occurs during the Pilkada, and patronage in employees, which is the provision of assistance from the ASN, not an official success team, to candidates for regional heads. They are trying to make the regional head candidate they support win the regional head election in the hope of obtaining an imbalance, especially ASN who occupy the position of head of the service or head of an agency.

The various modes of political corruption that occur also emphasize the vulnerability of distributive politics at the local level due to the broad translation of the discretion of regional authority; the management 
of public resources remains under the dominance of regional heads. The phenomenon of state capture proves that competitive electoral democracy has not yet produced significant changes in governance for the public's welfare. The government must immediately make efforts to eradicate political corruption a priority, not reproduce oligarchic distributive politics. Finally, fundamental changes must be made in the party system because political parties are a recruitment source for policymakers.

\section{References}

Akbar P, Taufik M, Irawan B, \& Sudiar S (2021) The face of the general elections commission in the case of the code of conduct. Journal of Government and Political Issues 1 (1):26-34.

Budi A, Sukmajati M, \& Prasetyo W (2018) Kampanye padat modal oleh calon perseorangan: Studi kasus Pilkada Kota Madiun 2018. In: Sukmajati M \& Perdana A (ed). Pembiayaan Pemilu di Indonesia. Jakarta: Bawaslu RI 163-184. https://www.bawaslu.go.id/sites/default/files/publikasi/ Pembiayaan\%20Pemilu_0.pdf.

Corstange D (2018) Clientelism in competitive and uncompetitive elections. Comparative Political Studies 51 (1):76-104. https://doi.org/10.1177/0010414017695332.

Cox GW (2010) Swing Voters, Core Voters, and Distributive Politics. In: Shapiro I, Stokes SC, Wood EJ, \& Kirshner AS (ed). Political Representation. Cambridge: Cambridge University Press 342357. https://doi.org/10.1017/CBO9780511813146.015.

Dalilah E, Selawati B, Pratama F, \& Wijayanti A (2019) Benturan kepentingan pada pendanaan Pilkada. Jurnal Antikorupsi INTEGRITAS 5 (1):181-188. https://doi.org/10.32697/integritas.v5i1.391.

Dasahasta R, Fariha L, Mubarok J, Badoh F, Simamora NN, Biky A, \& Saenong IB (2013) No impunity, melawan korupsi politik laporan masyarakat sipil tentang implementasi UNCAC di Indonesia. [Accessed 09 April 2020]. http://mappifhui.org/wp-content/uploads/2015/10/CSO-reportUNCAC1.pdf.

Defianti I (2018) La Nyalla: Saya dimaki-maki Prabowo, disuruh bayar uang saksi. Liputan 6, 12 January. [Accessed 20 March 2020]. https:/www.liputan6.com/news/read/3223582/la-nyallasaya-dimaki-maki-prabowo-disuruh-bayar-uang-saksi.

Fisman R \& Golden MA (2017) Corruption: What Everyone Needs to Know. New York: Oxford University Press.

Fitriyah \& Alfirdaus LK (2018) Botoh dan Pembiayaan Pilkada Alternatif. In: Sukmajati M \& Perdana A (ed). Pembiayaan Pemilu di Indonesia. Jakarta: Bawaslu RI 185-202. https://www.bawaslu.go.id/ sites/default/files/publikasi/Pembiayaan\%20Pemilu_0.pdf.

Gans-Morse J, Mazzuca S, \& Nichter S (2014) Varieties of clientelism: Machine politics during elections. American Journal of Political Science 58 (2):415-432. https://doi.org/10.1111/ajps.12058.

Gong T \& Scott I (2017) Routledge Handbook of Corruption in Asia. New York: Routledge.

Habibi M (2020) Ijon politik izin usaha pertambangan bentuk patronase dan klientelisme dalam Pemilukada Kalimantan Timur Tahun 2018. Dissertation, Universitas Muhammadiyah Yogyakarta, Yogyakarta.

Habibi M \& Suswanta S (2019) Politics discretionary fund budget of regional income and expenditure before and election in 2015 in Samarinda City. Journal of Governance and Public Policy 6 (1):2942. https://doi.org/10.18196/jgpp.61106.

Heidenheimer AJ \& Johnston M (2007) Political Corruption: Concepts and Contexts 3rd Edition. London: Transaction Publishers.

Heywood P (1997) Political corruption: Problems and perspectives. Political Studies 45 (3):417-435. https://doi.org/10.1111/1467-9248.00089.

Heywood PM (2015) Routledge Handbook of Political Corruption. London dan New York: Routledge.

Hicken A(2011) Clientelism. Annual Review of Political Science 14 (1):289-310. https://doi.org/10.1146/ annurev.polisci.031908.220508.

Hoesein ZA (2010) Pemilu kepala daerah dalam transisi demokrasi. Jurnal Konstitusi 7 (6):1-24.

ICW (2018) Outlook korupsi politik Indonesia 2018. [Accessed 28 March 2020]. https://antikorupsi. org/sites/default/files/outlook_korupsi_politik_2018_110118.pdf. 
Irham MA (2016) Korupsi demokratis dalam partai politik: Studi kasus penyelenggaraan Pemilukada Lampung. MASYARAKAT: Jurnal Sosiologi 21 (1):35-56. https://doi.org/10.7454/mjs. v21i1.4799.

Katadata (2020) KPK duga ada tambang dan kebun ilegal dilindungi petinggi bersenjata. Kata Data, 4 December. [Accessed 28 March 2020]. https://katadata.co.id/berita/2018/12/04/kpk-duga-adatambang-dan-kebun-ilegal-dilindungi-petinggi-bersenjata.

Kawata J (2006) Comparing Political Corruption and Clientelism. London: Routledge.

Kitschelt H (2000) Linkages between citizens and politicians in democratic polities. Comparative Political Studies 33 (6):845-879. https://doi.org/10.1177/001041400003300607.

Kitschelt H \& Wilkinson SI (2009) Patrons, Clients and Policies: Patterns of Democratic Accountability and Political Competition. Cambridge: Cambridge University Press. https://doi.org/https://doi. org/10.1017/CBO9780511585869.

KPK (2021) Statistik TPK berdasarkan profesi/jabatan. [Accessed 31 July 2021]. https://www.kpk. go.id/id/statistik/penindakan/tpk-berdasarkan-profesi-jabatan.

Kurer O (2001) Why do Voters Support Corrupt Politicians? In: Jain AK (ed). The Political Economy of Corruption. London: Routledge. 63-84.

LSI (2021) Rilis LSI survei politik uang 10 Januari 2021, pilkada dan politik uang di masa wabah COVID-19. [Accessed 31 July 2021]. http://www.lsi.or.id/riset/452/rilis-lsi-survei-politik-uang10-januari-2021.

Mietzner M (2015) Dysfunction by design: Political finance and corruption in Indonesia. Critical Asian Studies 47 (4):587-610. https://doi.org/10.1080/14672715.2015.1079991.

Miles MB, Huberman AM, \& Saldaña J (2014) Qualitative Data Analysis (Edition 3). Los Angeles: Arizona State University.

Muhtadi B (2018) Komoditas Demokrasi: Efek Sistem Pemilu terhadap Maraknya Jual Beli Suara. In: Sukmajati M \& Perdana A (ed). Pembiayaan Pemilu di Indonesia. Jakarta: Bawaslu RI. 95-117. https://www.bawaslu.go.id/sites/default/files/publikasi/Pembiayaan\%20Pemilu_0.pdf.

Nursanti A (2018) Gagal maju Pilwalkot Cirebon, Siswandi akui diminta mahar. Pikiran Rakyat, 13 January. [Accessed 01 July 2021]. https://www.pikiran-rakyat.com/jawa-barat/pr-01292281/ gagal-maju-pilwalkot-cirebon-siswandi-akui-diminta-mahar-417814.

Nye JS (1967) Corruption and political development: A cost-benefit analysis. The American Political Science Review 61 (2):417-427. https://doi.org/10.2307/1953254.

Olken BA \& Barron P (2007) The simple economics of extortion. Journal of Political Economy 117 (3):417-452. https://doi.org/http://dx.doi.org/10.1086/599707.

Popa M (2014) The distributive effects of corruption. Political Science Research and Methods 2 (2):273296. https://doi.org/10.1017/psrm.2013.29.

Pusat Penelitian dan Pengembangan Pengawasan BPKP (2018) Faktor-faktor penyebab kepala daerah korupsi. [Accessed 01 July 2020]. http://www.bpkp.go.id/puslitbangwas/konten/2674/16.050Faktor-Faktor-Penyebab-Kepala-Daerah-Korupsi.

Rose-Ackerman S (1999) Political corruption and democracy. Journal of International Law 14 (2):363378. https://digitalcommons.law.yale.edu/fss_papers/592/.

Saubani A (2020) Survei KPK ungkap banyak calon kepala daerah disponsori ASN. Republika, 5 August. [Accessed 04 July 2021]. https://www.republika.co.id/berita/qeky6d409/survei-kpkungkap-banyak-calon-kepala-daerah-disponsori-asn.

Scott JC (1972) Patron-client politics and political change in Southeast Asia. The American Political Science Review 66 (1):91-113. https://doi.org/10.2307/1959280.

Shleifer A \& Vishny RW (1993). Corruption. The Quarterly Journal of Economics 108 (3):599-617. https://doi.org/10.2307/2118402.

Singer M (2009) Buying voters with dirty money: The relationship between clientelism and corruption corruption. In: APSA 2009 Toronto Meeting Paper. Toronto: American Political Science Association's 1-24. https://papers.ssrn.com/sol3/papers.cfm?abstract_id=1449001.

Stokes SC, Dunning T, Nazareno M, \& Brusco V (2012) Brokers, voters, and clientelism. New Haven, Connecticut: Yale University and Universidad Nacional de Cordoba. https://doi.org/10.1017/ cbo9781107324909. 
TII (2017) Indeks Persepsi Korupsi Indonesia 2017. [Accessed 01 July 2020]. http://riset.ti.or.id/wpcontent/uploads/2018/09/IPK-2017_Report1.pdf.

Trantidis A \& Tsagkroni V (2017) Clientelism and corruption: Institutional adaptation of state capture strategies in view of resource scarcity in Greece. British Journal of Politics and International Relations 19 (2):263-281. https://doi.org/10.1177/1369148117700658.

You J (2014) Democracy, Inequality and Corruption: Korea, Taiwan and the Philippines Compared. Cambridge: Cambridge University Press. 